(RESEARCH ARTICLE)

\title{
Effect of different lighting regime on growth and reproductive performance of the Guinea fowl (Numida meleagris)
}

\author{
Clement Gyeabour Kyere 1, ${ }^{*}$, Okyere Korankye ${ }^{1}$, Addison Duodu 1, Grace Twumasi ${ }^{1}$ and Philip Kwaku \\ Dapaah ${ }^{2}$
}

\begin{abstract}
${ }^{1}$ Department of Animal Science Education, Faculty of Agriculture Education, University of Education, Winneba, Post Office Box 40, Mampong-Ashanti, Ghana.

${ }^{2}$ Department of Science Education, St. Teresa's College of Education, Affiliated to University of Cape Coast, Post Office Box 129, Hohoe Volta Rgion, Ghana.
\end{abstract}

Publication history: Received on 13 August 2020; revised on 24 August 2020; accepted on 28 August 2020

Article DOI: https://doi.org/10.30574/wjarr.2020.7.2.0306

\begin{abstract}
This study was conducted to investigate the influence of different lighting regime on reproductive and growth performance of the pearl Guinea fowl (Numida meleagris) in Ghana. A total of five hundred (500) eggs were collected from an ongoing photoperiod experiment which were hatched and used for the study. The experimental birds were randomly assigned to a lighting programme of 12 hours of light: 12 hours of darkness (12L: 12D), 14 hours of light: 10 hours of darkness (14L: 10D), 16 hours of light: 8 hours of darkness (16L: 8D), and 18 hours of light: 6 hours of darkness (18L: 6D). A total of two-hundred and forty (240) day one old keets were divided into four treatment groups and each treatment was replicated three times in a Completely Randomize Design (CRD). The data collected were subjected to analysis of variance (ANOVA) using GenStat version 11.1 (2008). Least significant difference (LSD) at $5 \%$ was used to separate the means. Results from the study revealed that, Percentage fertility, hatchability and hen-day egg production was highest $(\mathrm{P}<0.05)$ among Guinea fowls subjected to $16 \mathrm{~L}$ : 8D photoperiodic lighting schedule. Egg weight, dead in shell and piped eggs were highest $(\mathrm{P}<0.05)$ among Guinea fowls subjected to $12 \mathrm{~L}: 12 \mathrm{D}$ photoperiodic lighting schedule. Guinea fowls subjected to 18L: 6D lighting schedule had the highest $(\mathrm{P}<0.05)$ body weight, body weight gain, feed intake with better feed conversion ratio. This study concludes that 16L: 8D improves fertility, hatchability and hen-day egg production while 18L: 6D ensures rapid growth with better feed conversion.
\end{abstract}

Keywords: Day length; Maturity; Laying performance; Fertility; Hatchability

\section{Introduction}

Among all the poultry species raised in West Africa, Guinea fowl is gaining much popularity [1]. The bird is domesticated and commonly found in West and Central Africa and many European countries such as France and Italy [2]. Guinea fowl production in Ghana is regarded as an alternative way to reduce poverty among the people living in the rural areas. This is due to the fact that, the meat and eggs of local Guinea fowl is accepted for food locally without any restrictions [1, 3]. This indicates that there is the need for local farmers to increase the productivity of the bird. The performance of the bird can be improve through good management practices such as day length management, nutrition, suitable Guinea fowl production systems among others [4].

Suitable Guinea fowl production system such as good housing, good feeding practices and adequate day length result in high growth and productivity [5]. Globally, poultry birds are reared in a variety of production systems which include outdoor enclosures that basically utilize natural climatic conditions, production house of various sizes and

\footnotetext{
${ }^{*}$ Corresponding author: Clement Gyeabour Kyere

Department of Animal Science Education, Faculty of Agriculture Education, University of Education, Winneba, Post Office Box 40, Mampong-Ashanti, Ghana
}

Copyright (C) 2020 Author(s) retain the copyright of this article. This article is published under the terms of the Creative Commons Attribution Liscense 4.0. 
constructions that have little to extensive control over light and other environmental factors [6]. Increased in environmental complexity in poultry production and management is recognized as a means to achieve maximum productivity of Guinea fowl meat and eggs which also aim to resolve welfare concerns [4].

The major constrains to Guinea fowl production are poor nutrition, egg size, changes in day length and poor management practices [4, 7]. Differences in day length across the three different seasons in Ghana are single out as the major hindrance affecting Guinea fowl productivity. Guinea fowls are known to be seasonal breeders and therefore, their productivity depends on proper nutrition and day length. For instance, considering egg laying, Guinea hens do not lay eggs during shorter day length observed in some seasons in the year [4,8]. According to Lien et al. [9] the production and reproductive performance of commercial layer birds is influence by day length. In Guinea fowl production, light is one of the most influential microclimatic factors which enhance growth, physiological functioning and reproductive performance [4]. Light plays an important role in the physiological and behavioural processes in Guinea fowls and other poultry species. Light is integral to vision in birds, including both visual acuity and colour discrimination [10].

The supply of artificial light allows the bird to establish rhythmicity and synchronize many essential functions, including body temperature and metabolic processes that facilitate feeding and digestion in birds [10, 11]. Looking at the physiological prospective of the bird, adequate light stimulates secretory glands of several hormones that control growth, maturation, and egg production [11]. Lien et al. [9] further reported that typically poor egg production during summer is a consequence of insufficient lighting and reduce photoperiodic drive and in Guinea fowls, this can be improved by increasing day length through artificial means. Different lighting regime in poultry production is a topic of increasing importance's and concern among Guinea fowl breeders and local farmers. In view of the limited information on the influence of different lighting regime in Guinea fowl production, there is the need to undertake investigations aiming to determine the effect of different lighting regime on growth and reproductive performance of the Guinea fowl (Numida meleagris).

The ultimate aim of this experiment was to investigate the influence of different lighting regime on growth and reproductive performance of the Guinea fowl (Numida meleagris).

\section{Material and methods}

\subsection{Study location and duration}

The study was carried out at the Poultry Unit of the Animal farm of the Department of Animal Science Education, University of Education, Winneba, Mampong-Ashanti campus, Ghana. Mampong-Ashanti lies in the transitional zone between the Guinea savanna zone of the north and the tropical rain forest of the south of Ghana along the Kumasi-Ejura road. Mampong lies on latitude $07^{\circ} 03^{\prime} \mathrm{N}$ and longitude $01^{\circ} 24^{\prime} \mathrm{W}$, on an altitude of $289.7 \mathrm{~m}$ above sea level. The rainfall pattern is bimodal, with the major rainfall season occurring from April to July with $1000 \mathrm{~mm}$ of rainfall while the minor season occurs from August to November with $350 \mathrm{~mm}$ of rainfall. The average daily temperature was between $25{ }^{\circ} \mathrm{C}$ and $30{ }^{\circ} \mathrm{C}$ and the average relative humidity of the area is $70 \%$. The experiment lasted for twenty-four (24) weeks.

\subsection{Experimental birds, design and treatment}

The pearl variety of Guinea fowl was used for the study. A total of five hundred eggs were collected from an ongoing photoperiod experiment which were hatched and used for the study. Out of the over three hundred keets hatched, a total of 240 day old keets were randomly selected and used for the experiment. Each treatment had sixty (60) birds. The birds were brooded for four weeks and subjected to natural daylight and darkness before being transferred to a deep litter floored house. Each group was randomly assigned to a lighting programme of 12 hours of light: 12 hours of darkness as treatment one (T1), 14 hours of light: 10 hours of darkness (T2), 16 hours of light: 8 hours of darkness (T3) and 18 hours of light: 6 hours of darkness (T4) using bright energy saving bulbs of 50 watts and a supplemented rechargeable lamp incase of light out situation which also contain 40 watts with an average light intensity of 5.60 lux. The birds were divided into four treatment groups and each was replicated three times in a Completely Randomize Design (CRD).

\subsection{Housing, Feeding and Medication}

A total of twelve (12) experimental cages were used for rearing the birds, each measuring $1.4 \mathrm{~m} \times 1.34 \mathrm{~m}$ and housed twenty (20) birds. The floor was concreted, and wood shavings were used as litter for the birds. Removable wooden feeding troughs measuring $0.8 \mathrm{~m} \times 0.04 \mathrm{~m} \times 0.03 \mathrm{~m}$ were used for feeding the growers. A 4.5 liter watering trough was used for supplying water ad libitum for the growers in each cage. The experimental diets were supplied to the birds ad libitum throughout the experimental period. Vaccination and other routine poultry practices were also carried out. 


\subsection{Parameters Measured}

Parameters measured included: egg weight, hen-day egg production, fertility, hatchability, dead in shell and piped eggs, body weight, body weight gain, feed intake, feed conversion ratio,.

\subsubsection{Egg weight}

Egg weight was determined by weighing individual eggs collected daily with the use of A\&D Weighing EK-6000i electronic balance.

\subsubsection{Hen day egg production}

Hen day egg production was therefore calculated as the percentage of the number of eggs laid to the number of hen days. HDEP $=\frac{\text { Number of eggs laid }}{\text { Number of hen days }} \times 100 \%$

\subsubsection{Percentage fertility}

Percentage fertility was calculated by expressing the total number of fertile eggs as a percentage of the total number of eggs set. Arithmetically, \% Fertility $=\frac{\text { Total number of fertile eggs }}{\text { Total number of eggs set }} \times 100$

\subsubsection{Percentage hatchability}

Percentage hatchability was determined as the total number of eggs hatched as a percentage of total number of fertile eggs. \%Hatchability $=\frac{\text { Total number of Guinea keets hacthed }}{\text { Total number of fertile eggs }} \times 100$

\subsubsection{Dead in shell and piped eggs}

Number of dead in shell was determined by breaking the un-hatched eggs. Number of piped was determined by checking for those eggs that cracked but the keets did not emerge.

\subsubsection{Body weight and body weight gain}

Body weight: Birds were weighed at the start of the experiment and also at weekly intervals using A\&D Weighing EK6000 i electronic balance (A\&D Co. Ltd, USA). Body weight gain (g/bird) was calculated by subtracting the initial weight from their final weights.

\subsubsection{Feed intake and feed conversion ratio}

Feed intake was calculated as the difference between the initial feed offered to birds and the feed left over. Feed conversion ratio (FCR) was computed as the feed intake divided by the total weight gain. Arithmetically, FCR = Total feed intake (g)

Total weight gain $(\mathrm{g})$

\subsection{Data Analysis}

The data collected were analyzed using the one-way analysis of variance (ANOVA) according to the procedure of Steel and Torrie [12] and the treatment means were separated by the least significant difference (LSD) to determine which of the treatments has significance difference or not at $5 \%$ probability level.

\section{Results}

\subsection{Effect of different lighting regime on reproductive performance}

The different lighting regime affected reproductive performance (Table 1). Percentage fertility, hatchability and henday egg production of Guinea fowls subjected to 16L: 8D photoperiodic lighting schedule significantly $(\mathrm{P}<0.05)$ increased as compared to all other photoperiodic lighting schedule. Egg weight, dead in shell and piped eggs were observed to be highest $(\mathrm{P}<0.05)$ among Guinea fowls subjected to $12 \mathrm{~L}: 12 \mathrm{D}$ photoperiodic lighting schedule and lowest $(\mathrm{P}<0.05)$ among Guinea fowls subjected to 16L: 8D photoperiodic lighting schedule. 
Table 1 Effect of different lighting regime on reproductive performance.

\begin{tabular}{|l|l|l|l|l|l|l|}
\hline Treatment/ Parameters & $\begin{array}{l}\text { T1 } \\
\text { (12 L: 12 D) }\end{array}$ & $\begin{array}{l}\text { T2 } \\
\text { (14 L: 10 D) }\end{array}$ & $\begin{array}{l}\text { T3 } \\
\text { (16 L: 8 D) }\end{array}$ & $\begin{array}{l}\text { T4 } \\
\text { (18 L: 6 D) }\end{array}$ & S.E.M & P-value \\
\hline Fertility (\%) & $52.84^{\mathrm{d}}$ & $54.68^{\mathrm{c}}$ & $60.56^{\mathrm{a}}$ & $56.72^{\mathrm{b}}$ & 2.324 & 0.001 \\
\hline Hatchability (\%) & $45.89^{\mathrm{b}}$ & $53.12^{\mathrm{c}}$ & $58.92^{\mathrm{a}}$ & $52.35^{\mathrm{c}}$ & 2.891 & 0.001 \\
\hline Dead in shell & $20.35^{\mathrm{a}}$ & $16.89^{\mathrm{b}}$ & $13.68^{\mathrm{c}}$ & $15.48^{\mathrm{b}}$ & 2.481 & 0.001 \\
\hline Piped eggs & $13.58^{\mathrm{a}}$ & $13.12^{\mathrm{a}}$ & $6.981^{\mathrm{c}}$ & $8.391^{\mathrm{b}}$ & 1.982 & 0.001 \\
\hline Egg weight (g) & $43.25^{\mathrm{a}}$ & $41.58^{\mathrm{b}}$ & $39.25^{\mathrm{c}}$ & $39.45^{\mathrm{c}}$ & 2.011 & 0.001 \\
\hline Hen-day egg production (\%) & $65.42^{\mathrm{b}}$ & $63.81^{\mathrm{c}}$ & $68.25^{\mathrm{a}}$ & $66.45^{\mathrm{b}}$ & 1.561 & 0.002 \\
\hline
\end{tabular}

Means bearing different superscripts in the same row are significantly different ( $<<0.05), 12 \mathrm{~L}: 12 \mathrm{D}=12$ hours of light: 12 hours of darkness, 14 L: $10 \mathrm{D}=14$ hours of light: 10 hours of darkness, 16 L: $8 \mathrm{D}=16$ hours of light: 8 hours of darkness, 18 L: 6 D = 18 hours of light: 6 hours of darkness.

\subsection{Effect of different lighting regime on body weight}

Different lighting regime significantly $(\mathrm{P}<0.05)$ affected body weight of pearl Guinea fowls from four weeks up to sixteen weeks of age. However, after sixteen weeks of age no significant $(P>0.05)$ differences were observed among the treatment groups (Table 2). Body weight of pearl Guinea fowls subjected to 18L: 6D lighting schedule significantly $(\mathrm{P}<0.05)$ increased from four weeks up to sixteen weeks of age followed by Guinea fowls subjected to 16L: 8D and 14L: 10D lighting schedule respectively. While birds subjected to 12L: 12D lighting schedule had the lowest body weight.

Table 2 Effect of different lighting regime on body weight

\begin{tabular}{|c|c|c|c|c|c|c|}
\hline $\begin{array}{l}\text { Treatment/ } \\
\text { Parameters }\end{array}$ & $\begin{array}{l}\text { T1 } \\
\text { (12 L: } 12 \text { D) }\end{array}$ & $\begin{array}{l}\text { T2 } \\
\text { (14 L: } 10 \text { D) }\end{array}$ & $\begin{array}{l}\text { T3 } \\
\text { (16 L: } 8 \text { D) }\end{array}$ & $\begin{array}{l}\text { T4 } \\
\text { (18 L: 6 D) }\end{array}$ & S.E.M & P-value \\
\hline Day old (g) & 26.23 & 26.25 & 26.29 & 26.51 & 0.301 & 0.121 \\
\hline 4 Weeks (g) & $188.11^{b}$ & $189.74^{b}$ & $190.02^{\mathrm{ab}}$ & $196.14^{a}$ & 6.532 & 0.015 \\
\hline 8 Weeks (g) & $328.81^{c}$ & $335.31^{b}$ & $337.43^{b}$ & $348.01^{\mathrm{a}}$ & 5.74 & 0.018 \\
\hline 12 Weeks (g) & $523.29^{c}$ & $542.11^{\mathrm{b}}$ & $543.77^{b}$ & $585.22^{\mathrm{a}}$ & 15.48 & 0.013 \\
\hline 16 Weeks (g) & $743.29^{c}$ & $812.11^{b}$ & $813.7^{b}$ & $825.22^{\mathrm{a}}$ & 15.48 & 0.013 \\
\hline 20 Weeks (kg) & 1.052 & 1.019 & 1.076 & 1.068 & 0.421 & 0.498 \\
\hline 24 Weeks (kg) & 1.235 & 1.218 & 1.295 & 1.291 & 0.488 & 0.458 \\
\hline
\end{tabular}

Means bearing different superscripts in the same row are significantly different $(\mathrm{P}<0.05), 12 \mathrm{~L}: 12 \mathrm{D}=12$ hours of light: 12 hours of darkness, $14 \mathrm{~L}$ : $10 \mathrm{D}=14$ hours of light: 10 hours of darkness, $16 \mathrm{~L}: 8 \mathrm{D}=16$ hours of light: 8 hours of darkness, $18 \mathrm{~L}: 6 \mathrm{D}=18$ hours of light: 6 hours of darkness.

\subsection{Effect of different lighting regime on body weight gain}

Different lighting regime had significantly $(\mathrm{P}<0.05)$ effect on body weight gain throughout the period of study except the first eight weeks of age (Table 3). Body weight gain of the pearl Guinea fowl increased with increasing day length up to 18L: 6D lighting schedule except at 17 to 20 weeks. Birds subjected to 18L: 6D lighting schedule gain the highest $(\mathrm{P}<0.05)$ weight followed by Guinea fowls subjected to 16L: 8D and 14L: 10D lighting schedule respectively. Birds subjected to 12L: 12D lighting schedule had the lowest body weight gain. However, at 17 to 20 weeks of age, birds subjected to 12L: 12D lighting schedule gain the highest $(\mathrm{P}<0.05)$ weight followed by Guinea fowls subjected to 14L: 10D, 16L: 8D and 14L: 10D lighting schedule respectively. 
Table 3 Effect of different lighting regime on body weight gain

\begin{tabular}{|l|l|l|l|l|l|l|}
\hline $\begin{array}{l}\text { Treatment/ } \\
\text { Parameters }\end{array}$ & $\begin{array}{l}\text { T1 } \\
\text { (12 L: 12 D) }\end{array}$ & $\begin{array}{l}\text { T2 } \\
\text { (14 L: 10 D) }\end{array}$ & $\begin{array}{l}\text { T3 } \\
\text { (16 L: 8 D) }\end{array}$ & $\begin{array}{l}\text { T4 } \\
\text { (18 L: 6 D) }\end{array}$ & S.E.M & P-value \\
\hline 0-4 Weeks (g) & 162.28 & 163.49 & 163.73 & 164.03 & 2.871 & 0.098 \\
\hline 5-8 Weeks (g) & 140.70 & 145.57 & 147.41 & 151.87 & 2.182 & 0.121 \\
\hline 9-12 Weeks (g) & $194.48^{\mathrm{c}}$ & $206.80^{\mathrm{b}}$ & $206.34^{\mathrm{b}}$ & $237.21^{\mathrm{a}}$ & 2.485 & 0.001 \\
\hline 13-16 Weeks (g) & $220.00^{\mathrm{c}}$ & $270.00^{\mathrm{a}}$ & $270.00^{\mathrm{a}}$ & $259.00^{\mathrm{b}}$ & 1.084 & 0.001 \\
\hline 17-20 Weeks (g) & $308.71^{\mathrm{a}}$ & $206.89^{\mathrm{d}}$ & $262.23^{\mathrm{b}}$ & $242.78^{\mathrm{c}}$ & 0.874 & 0.001 \\
\hline 21-24 Weeks (g) & 183.00 & $219.00^{\mathrm{b}}$ & $219.00^{\mathrm{b}}$ & $223.00^{\mathrm{a}}$ & 2.341 & 0.001 \\
\hline
\end{tabular}

Means bearing different superscripts in the same row are significantly different $(\mathrm{P}<0.05), 12 \mathrm{~L}: 12 \mathrm{D}=12$ hours of light: 12 hours of darkness, $14 \mathrm{~L}$ : $10 \mathrm{D}=14$ hours of light: 10 hours of darkness, 16L: 8D=16 hours of light: 8 hours of darkness, 18L: 6D = 18 hours of light: 6 hours of darkness.

\subsection{Effect of different lighting regime on feed intake}

Table 4 presents the feed intake across the period of study. Feed intake was observed to be significant $(\mathrm{P}<0.05)$ across the period of study except $(\mathrm{P}>0.05)$ at 0-4 and 13-16 weeks of age. Feed intake increased with increasing day length. Guinea fowls subjected to 18L: 6D photoperiodic lighting schedule significantly $(\mathrm{P}<0.05)$ recorded the highest feed intake followed by 16L: 8D, 14L: 10D and lowest among birds on the 12L: 12D photoperiodic lighting schedule.

Table 4 Effect of different lighting regime on feed intake

\begin{tabular}{|l|l|l|l|l|l|l|}
\hline $\begin{array}{l}\text { Treatment/ } \\
\text { Parameters }\end{array}$ & $\begin{array}{l}\text { T1 } \\
\text { (12 L: 12 D) }\end{array}$ & $\begin{array}{l}\text { T2 } \\
\text { (14 L: 10 D) }\end{array}$ & $\begin{array}{l}\text { T3 } \\
\text { (16 L: 8 D) }\end{array}$ & $\begin{array}{l}\text { T4 } \\
\text { (18 L: 6 D) }\end{array}$ & S.E.M & P-value \\
\hline 0-4 Weeks (g) & 315.51 & $320.44^{-}$ & 321.22 & 329.56 & 3.561 & 0.114 \\
\hline 5-8 Weeks (g) & $409.80^{c}$ & $407.61^{\mathrm{c}}$ & $413.89^{\mathrm{b}}$ & $416.72^{\mathrm{a}}$ & 2.832 & 0.002 \\
\hline 9-12 Weeks (g) & $526.0^{\mathrm{c}}$ & $542.8^{\mathrm{c}}$ & $549.20^{\mathrm{b}}$ & $558.21^{\mathrm{a}}$ & 4.981 & 0.001 \\
\hline 13-16 Weeks (g) & 670.90 & 669.51 & 670.85 & $670.32^{-}$ & 2.821 & 0.231 \\
\hline 17-20 Weeks (g) & $720.50^{\mathrm{b}}$ & $710.11^{\mathrm{c}}$ & $681.21^{\mathrm{d}}$ & $735.00^{\mathrm{a}}$ & 8.791 & 0.002 \\
\hline 21-24 Weeks (g) & $735.22^{\mathrm{b}}$ & $729.81^{\mathrm{b}}$ & $785.31^{\mathrm{a}}$ & $793.24^{\mathrm{a}}$ & 11.83 & 0.006 \\
\hline
\end{tabular}

Means bearing different superscripts in the same row are significantly different (P<0.05), $12 \mathrm{~L}: 12 \mathrm{D}=12$ hours of light: 12 hours of darkness, $14 \mathrm{~L}$ : $10 \mathrm{D}=14$ hours of light: 10 hours of darkness, $16 \mathrm{~L}: 8 \mathrm{D}=16$ hours of light: 8 hours of darkness, $18 \mathrm{~L}: 6 \mathrm{D}=18$ hours of light: 6 hours of darkness.

\subsection{Effect of different lighting regime on feed conversion ratio}

Table 5 shows the feed conversion ratio across the period of study. Different lighting regime had significantly $(\mathrm{P}<0.05)$ effect on feed conversion ratio at 5-8, 9-12 and 13-16 weeks of age (Table 5).

Table 5 Effect of different lighting regime on feed conversion ratio

\begin{tabular}{|l|l|l|l|l|l|l|}
\hline $\begin{array}{l}\text { Treatment/ } \\
\text { Parameters }\end{array}$ & $\begin{array}{l}\text { T1 } \\
(\mathbf{1 2} \text { L : 12 D) }\end{array}$ & $\begin{array}{l}\text { T2 } \\
(\mathbf{1 4} \text { L : 10 D) }\end{array}$ & $\begin{array}{l}\text { T3 } \\
(\mathbf{1 6} \text { L : 8 D) }\end{array}$ & $\begin{array}{l}\text { T4 } \\
(\mathbf{1 8 ~ L ~}: \mathbf{6} \text { D) }\end{array}$ & S.E.M & P-value \\
\hline 0-4 Weeks & 1.944 & 1.960 & 1.962 & 1.949 & 0.681 & 0.116 \\
\hline 5-8 Weeks & $2.913^{\mathrm{a}}$ & $2.800^{\mathrm{b}}$ & $2.808^{\mathrm{b}}$ & $2.744^{\mathrm{c}}$ & 0.072 & 0.002 \\
\hline 9-12 Weeks & $2.708^{\mathrm{a}}$ & $2.624^{\mathrm{c}}$ & $2.662^{\mathrm{b}}$ & $2.353^{\mathrm{d}}$ & 0.286 & 0.001 \\
\hline 13-16 Weeks & $3.333^{\mathrm{c}}$ & $2.479^{\mathrm{b}}$ & $2.485^{\mathrm{b}}$ & $2.587^{\mathrm{a}}$ & 0.089 & 0.003 \\
\hline 17-20 Weeks & 3.937 & 3.432 & 2.590 & 3.027 & 1.087 & 0.349 \\
\hline 21-24 Weeks & 3.598 & 3.332 & 3.586 & 3.557 & 0.152 & 0.112 \\
\hline
\end{tabular}

Means bearing different superscripts in the same row are significantly different $(\mathrm{P}<0.05), 12 \mathrm{~L}: 12 \mathrm{D}=12$ hours of light: 12 hours of darkness, $14 \mathrm{~L}$ : $10 \mathrm{D}=14$ hours of light: 10 hours of darkness, 16L: 8D=16 hours of light: 8 hours of darkness, 18L: 6D = 18 hours of light: 6 hours of darkness. 
Feed conversion ratio at 5-8 and 9-12 weeks of age was observed to be better $(\mathrm{P}<0.05)$ followed by $16 \mathrm{~L}$ : 8D and 14L: 10D. However, Guinea fowls subjected to 12L: 12D photoperiodic lighting schedule had the poorest feed conversion ratio. At 13-16 weeks of age, the trend of feed conversion ratio changed. Guinea fowls subjected to 12L: 12D photoperiodic lighting schedule had the best feed conversion ratio as compared to the other photoperiodic lighting schedule.

\section{Discussion}

\subsection{Effect of different lighting regime on reproductive performance}

The significant increase in percentage fertility and hatchability of Guinea fowl eggs subjected to 16L: 8D photoperiodic lighting schedule could be explained that light is a fertility all-star, playing a make-it-or-break-it role in the functioning of the reproductive systems of Guinea fowl hens. This means that 16L: 8D photoperiodic lighting schedule is adequate enough to keep the circadian pacemaker (the body's master clock) in synch which stimulates higher production of Luteinizing Hormone (LH) and Follicle-stimulating hormone (FSH). These hormones are among some other hormones responsible for egg fertility. Also, this can be explained that 16L: 8D photoperiodic lighting schedule stimulate increase secretion of metabolic hormones ( $\mathrm{T}_{3}, \mathrm{~T}_{4}$, insulin, $\mathrm{GH}$ and IGF-1). All these hormones shared in development and enhancing productive and reproductive functions of domestic birds [13]. This study confirms earlier reports from the study of Shafey [14] who observed differences in fertility and hatchability among various layer strains, and attributed this to physical dimensions of the eggs allowing different light levels through. The study is also in agreement with studies conducted by Schwean et al. [15]. Additionally, egg weight decreased with increasing day length, and this result is similar to the findings of Lewis et al. [16]

The significant increase in hen-day egg production among Guinea fowls subjected to 16L: 8D photoperiodic lighting schedule could be explained that, 16L: 8D photoperiodic lighting schedule stimulate gonadal development, eventually resulting in onset of lay by stimulate the hypothalamus area via eyes or by pineal gland to release GnRH, which stimulate anterior pituitary to release FSH and LH [17]. These hormones are responsible for production of the major sex steroid hormone such as testosterone, estrogen and progesterone which helps the birds to lay more eggs. Again the increased in egg weight could be attributed to the higher estrogen levels among Guinea fowls subjected to 16L: 8D photoperiodic lighting schedule. Estrogen is necessary for yolk precursor lipoprotein secretion by the liver and oviduct and follicle development [18] leading to the production of large size eggs, reduce dead keets in the shells and piped eggs. This is comparable to earlier studies by Hassanzadeh et al. [19] who reported that when birds are given 16 hours of light it increased the level of estrogen in the blood which influenced globulin levels to increase egg size and yolk height. Egg size, yolk weight and height are positively correlated with globulin levels [19]. However, this result does not corroborate earlier report by Schaper et al. [19] who observed that light had no significant $(\mathrm{P}>0.05)$ effect on egg weight.

\subsection{Effect of different lighting regime on body weight and body weight gain}

Results regarding the effect of different lighting regime on body weight were consistent with substantial scientific evidence that longer day length during the growth period results in heavier body weights and body weight gain, because appetite was stimulated by photoperiod, which led to rapid early growth and enhanced skeletal development [21, 22]. However, results obtained in this study on body weight and body weight gain were not consistent with the results of Banks and Koen [23] who did not find a significant effect of lighting system during the growth phase on the average live body weight of birds during the production stage. Similarly, Shunshun et al. [11] also reported no significant effect of three lighting regimes during ten weeks growth phase of Pengxian yellow pullets. The variation in this study and the findings from literature may be because a day length of 6 hours provided enough light for normal feed and water access, which meets the requirement for growth development, and the longer day length possibly, may increase the feed intake. According to Shunshun et al. [11] there is a strong negative relationship between body weight and reproductive efficiency; therefore, the body weight of grower Guinea fowls should be controlled within reason.

\subsection{Effect of different lighting regime on feed intake and feed conversion ratio}

In this study it was observed that feed intake increased with increasing day length with better feed conversion ratio. This trend could be due to the fact that increasing day length allowed maximum feeding time, with birds consuming more feed. Physiologically, increases in day length inhibit the secretion of the hormone leptin (leptin is often referred as the satiety hormone) from the adipose cell and ensures that the birds will feed throughout the lightning period. This result is similar to what Mendes et al. [24] reported in turkeys subjected to three different lightening programmes on live weight and feed intake. Lewis et al. [10] reported that feed intake is highly influenced when birds are supplemented with artificial light more than 16L: 8D. Leeson et al. [21] also reported that longer day length during the growth period results in higher feed intakes and heavier body weights, because appetite was stimulated by photoperiod, which led to 
rapid early growth and enhanced skeletal development. Results on feed conversion ratio is in line with the findings of Classen et al. [25] who reported that early light restriction improved feed conversion ratio during the early phases of the grower stage in broiler chickens.

\section{Conclusion}

This study concludes that 16L: 8D photoperiodic lighting schedule increased percentage fertility, hatchability of Guinea fowl eggs and hen-day egg production. Guinea fowls subjected to 12L: 12D photoperiodic lighting schedule lay heavier eggs, recorded the highest dead in shell and piped eggs. Guinea fowls subjected to 18L: 6D lighting schedule had the highest body weight, body weight gain, feed intake with better feed conversion ratio.

\section{Compliance with ethical standards}

\section{Acknowledgments}

The authors are grateful to the Department of Animal Science Education, Faculty of Agriculture Education, University of Education, Winneba for providing facilities for this study.

\section{Disclosure of conflict of interest}

Authors have declared that, no conflict of interests exist.

\section{References}

[1] Annor SY, Apiiga SY, Ahiaba J. Guinea fowl production: A handbook. Accra, Ghana: Quality type Ltd. 2013.

[2] Duodu A, Annor SY, Kagya-Agyemang JK, Kyere CG. Influence of Strain on Production and Some Other Traits of Indigenous Guinea Fowls (Numida meleagris) in Ghana. Current Journal of Applied Science and Technology. 2018; $30(2): 1-7$.

[3] Naazie, A, Canacoo, EA, Mwinbong, C. Guinea Fowl Production Practices and Marketing in Northern Ghana. Agricultural Research Centre- Legon, College of Agriculture and Consumer Sciences. University of Ghana, Legon, Ghana. Ghana Journal of Animal Science. 2007;2 and 3(1): 35-44.

[4] Okyere K, Kagya-Agyemang JK, Annor SY, Asabere-Ameyaw A, Kyere CG. Influence of Season and Day Length on Production and Reproductive Traits and Egg Characteristics of the Guinea Fowl (Numida meleagris). Asian Journal of Research in Zoology. 2020; 3(1): 26-34.

[5] Saina H, Kusina NT, Kusina JF, Bhebhe E, Lebel S. Guinea fowl production by indigenous farmers in Zimbabwe. Livestock Research for Rural Development. 2005; 17(9).

[6] Naazie A, Canacoo EA, Mwinbong C. Guinea Fowl Production and Marketing in Northern Ghana. Ghanaian Journal of Animal Science. 2007; 2\&3(1), 38-40.

[7] Teye GA, Adam M. Constraints to Guinea fowl production in northern Ghana: A case study of the Damongo area. Ghana J. Agric. Sci. 2000; 33:153-157.

[8] Teye GA, Gyawu P. A Guide to Guinea Fowl Production in Ghana. Department of Animal Science. University for Development Studies, Tamale, Ghana. 2002; 14.

[9] Lien RJ, Hess JB, McKee SR, Bilgili SF, Townsend JC. Effect of light intensity and photoperiod on live performance, heterophil-to-lymphocyte ratio, and processing yields of broilers. Poultry Science. 2007; 86, 1287-1293.

[10] Lewis PD, Danisman R, Gous RM. Photoperiodic responses of broilers. III. Tibial breaking strength and ash content. British Poultry Science, 2009;50: 673-679.

[11] Shunshun H, Yan W, Lingyan L, Diyan L, Zihao L, Xiaoxu S, Hengyoung X, Xiaoling Z, Qing Z, Huadong Y. Influence of three lighting regimes during ten weeks growth phase on laying performance, plasma levels- and tissue specific gene expression- of reproductive hormones in Pengxian yellow pullets. 2017; 12 (5): e0177358.

[12] Statistical Analysis System (SAS). User's Guide. SAS/STAT® 9.2, Cary, NC: SAS Institute Inc. 2008.

[13] Mateescu RG, Thonney ML. Effect of testosterone on insulin-like growth factor-I, androgen receptor and myostatin gene expression in splenius and semitendinosus muscles in sheep. J. Anim. Sci.2005; 83: 803-809. 
[14] Shafey T. Effect of lighted incubation on embryonic growth and hatchability performance of two strains of layer breeder eggs. Br. Poult. Sci. 2004; 45 223-229.

[15] Schwean LK, Fancher BI, Classen HL. Impact of day length on the productivity of two commercial broiler strains. British Poultry Science. 2012; 53: 7-18.

[16] Lewis PD, Perry GC, Morris TR. Effect of 5 hour increases in photoperiod and in feeding opportunity on age at first egg. Br Poult Sci. 1996;37: 15-19.

[17] Chen W, Guo YM, Huang YQ, Shi YH, Zhang CX, Wang JW. Effect of light restriction on growth, slaughter performance, serum biochemical parameters and Lpin2/WDTC1 mRNA expression of broilers in the later phase. J. Poultry Sci. 2012; 49:12-19.

[18] Dawson A. Seasonal differences in the secretion of luteinizing hormone and prolactin in response to N-methylDL-aspartate in starlings (Sturnus vulgaris). J. Neuroendocrinol. 2005; 17: 105-110.

[19] Hassanzadeh M, Fard MH, Buyse J, Decuypere R. Beneficial effects of alternative lighting schedules on the incidence of ascites and on metabolic parameters of broiler chickens. Acta Vet. Hung. 2003; 51(4): 513-520.

[20] Schaper SV, Dawson A, Sharp PJ, Caro SP, Visser ME. Individual variation in avian reproductive physiology does not reliably predict variation in laying date. General and Comparative Edocrinology. 2012; 79:53-62.

[21] Leeson S, Caston L, Lewis PD. Rearing and laying performance following various step-down lighting regimens in the rearing period. Poultry Science. 200;84: 626-632.

[22] Lewis PD, Perry GC, Morris TR, Douthwaite JA, Bentley GE. Effect of constant and of changing photoperiod on plasma LH and FSH concentrations and age at first egg in layer strains of domestic pullets. Br Poult Sci. 1998;39: 662-670.

[23] Banks PA, Koen TP. Intermittent lighting regimens for laying hens. Journal of Poultry Science. 1989;68: 739-743.

[24] Mendes M, Karabayir A, Erosy E, Tasiglu C. (2005). The effect of three different lighting regime programme on live weight changes of bronze turkey under semi intensive condition. Arch. TierzDummerstovf. 2005; 48(1): 8693.

[25] Classen HL, Riddell C, F. E. Robinson FE. Effects of increasing photoperiod length on performance and health of broiler chickens. Brazilian Poultry Science. 1991; 32:21-29.

\section{Author's short biography}

Mr. Clement Gyeabour Kyere (B.Sc. Agricultural Science Education and MPhil) is a Research Coordinator of the Seventh-Day Adventist College of Education Agona-Ashanti. He is specialised in Animal Reproductive Physiology. He is skilful in handling statistical packages including Genstat and SPSS. He is also skilful in designing research and review of manuscript for publication.

Rev. Fr. Dr. Okyere Korankye (O and A Level Cert, Cert. A, B.Ed., MPhil and PhD). He is specialised in Animal Reproductive Physiology. He has over 20 years working experience with the Ghana Education service.

Dr. Addison Duodu (O and A Level Cert, Cert. A, B.Ed., M.Sc. and PhD). He is specialised in Animal Breeding and Genetics. He has over 18 years working experience with the Ghana Education service. Currently, He lectures in Principle of Animal Genetics and Breeding, Statistics and Biometry. 
Ms. Grace Twumasi (B.Sc. Agricultural Science Education). She is specialised in Animal Science.

Mr. Philip Kwaku Dapaah (0 and A Level Cert, Cert. A, B.E.d and MPhil). He is specialised in Post-Harvest Technology. He has over 5 years working experience with the Ghana Education service and 15 years working experience with the College of Education.
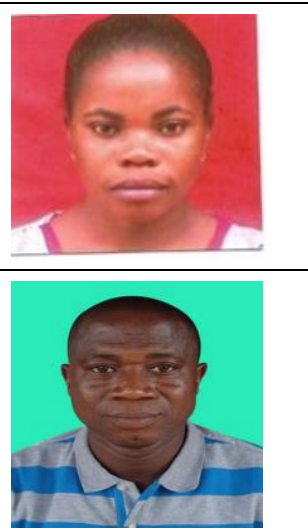